\title{
Serum total sialic acid levels in overt and subclinical hypothyroid patients and its relationship with atherosclerotic risk factors
}

${ }^{1}$ Mustafa Altay, ${ }^{1}$ Mehmet Ayhan Karakoç, ${ }^{1}$ Nuri Çakır, ${ }^{1}$ Ethem Turgay Cerit, ${ }^{1}$ Müjde Aktürk, ${ }^{2}$ Canan Yılmaz Demirtaş, ${ }^{2}$ Neslihan Bukan, ${ }^{1}$ Metin Arslan

Gazi University Medical Faculty, Department of Endocrinology and Metabolism, Ankara, TURKEY 2 Gazi University Medical Faculty, Clinical Biochemistry, Ankara, TURKEY

\section{OBJECTIVE}

Serum total sialic acid(SA) concentration is assessed as an up to date

risk indicator of atherosclerosis and cardiovascular diseases. It was

aimed to investigate about how SA levels are effected in overt or

subclinical hypothyroidism(SH) and how it's associated with other

atherosclerosis risk factors because there is no study about these topics,

though SA is intensively studied in recent years

\section{METHODS}

Sixthy newly diagnosed treatment-naive hypothyroid patients(35 subclinical and 25 overt) and 30 euthyroid individuals were included in the study. Fasting blood samples were taken and SA, serum homocystein and hsCRP was measured in addition to routin biochemical measurements and carotid artery intima media thickness(CIMT) measurements were performed.

Table 1. Demographic features and biochemical parameters of patients and controls

\begin{tabular}{|c|c|c|c|}
\hline & Control $(n=30)$ & Hypothyroid ( $n=60$ ) & $\mathrm{p}$ value \\
\hline $\operatorname{Sex}(m / f)$ & $5 / 25$ & $10 / 50$ & NS \\
\hline Age(year) & $32.5 \pm 7.5$ & $33.8 \pm 9.8$ & NS \\
\hline BMI & $23.7 \pm 3.9$ & $27.1 \pm 5.4$ & 0,001 \\
\hline WCR & $0.83 \pm 0.07$ & $0.88 \pm 0.09$ & 0,02 \\
\hline СіMT (mm) & $0.58 \pm 0.06$ & $0.62 \pm 0.12$ & 0,046 \\
\hline Total- K (mg/dL) & $176.5 \pm 31.4$ & $203.7 \pm 50.6$ & 0,003 \\
\hline HDL-K (mg/dL) & $52.4 \pm 10.4$ & $51.2 \pm 12.2$ & NS \\
\hline LDL-K (mg/dL) & $107.6 \pm 25.9$ & $128.5 \pm 41.2$ & 0,004 \\
\hline TSH ( $\mu \mathrm{I} \mathrm{U} / \mathrm{mL})$ & $1.5 \pm 0.7$ & $40.4 \pm 74.5$ & $<0,001$ \\
\hline MPV (fL) & $8.9 \pm 1$ & $8.6 \pm 1.3$ & NS \\
\hline Sialic asit $(\mu \mathrm{g} / \mathrm{mL})$ & $42 \pm 15.7$ & $44.5 \pm 19.1$ & NS \\
\hline hs $\operatorname{CRP}(\mathrm{mg} / \mathrm{dL})$ & $0.12 \pm 0.16$ & $0.2 \pm 0.24$ & 0,07 \\
\hline Homosist( $\mu \mathrm{mol} / \mathrm{L})$ & $14.7 \pm 6.3$ & $16.6 \pm 13.3$ & NS \\
\hline
\end{tabular}

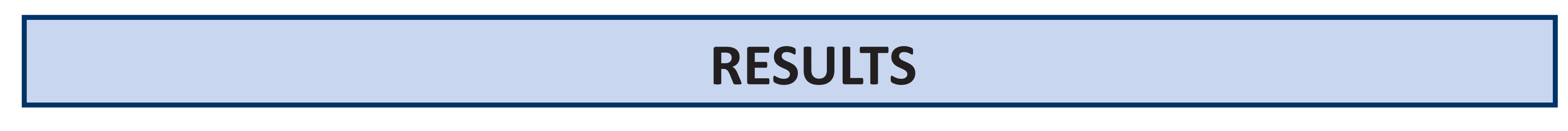

Diastolic blood pressure, CIMT, Total-C, LDL-C, TG levels were significantly increased in patients. Other atherogenesis related measurements such as systolic blood pressure, uric acid, hsCRP and homocystein levels were also increased in patients, but not statistically significant. Serum total SA levels were higher in hypotyroid patients compared to controls but the difference was not statistically significant. In patients' group positive correlation between CIMT and SA was determined as it was between SA and uric acid.

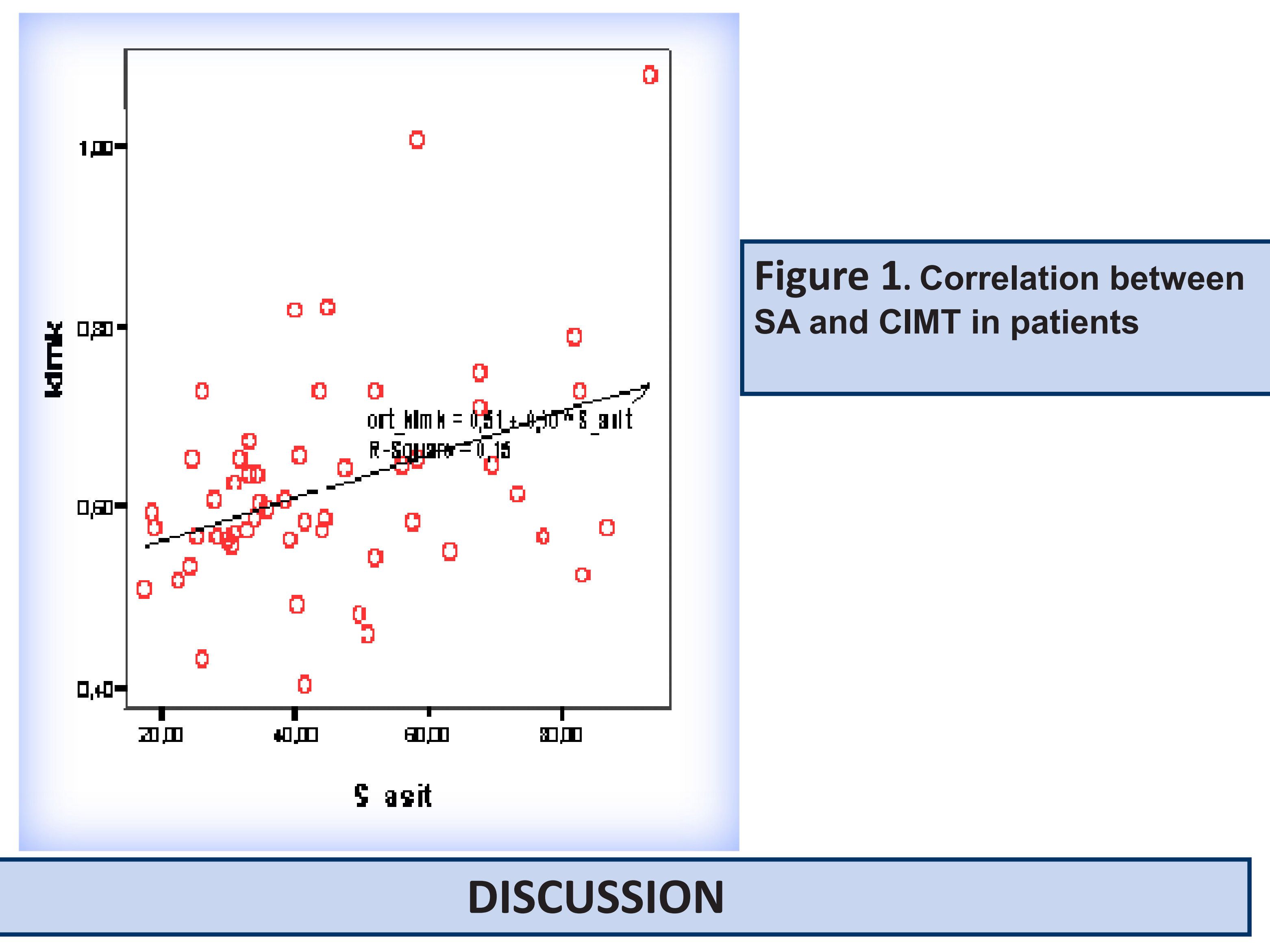

Interesting result of our study is the positive relationship between SA and CIMT which is revealed for the first time. The existence of correlation between SA and some indicators like CIMT, hsCRP and uric acid in hypothyroid group suggests that it can be an atherogenesis indicator in hypotyroid patients.

\section{REFERENCES}

1. Serdar Z, Yesilbursa D, Dirican M, Sarandol E, Serdar A. Sialic acid and oxidizability of lipid and proteins and antioxidant status in patients with coronary artery disease. Cell Biochem Funct. 2007; 25: 655-664.

2. Yilmaz FM, Akay H, Duranay M, Yilmaz G, Oztekin PS, Koșar U, et al. Carotid atherosclerosis and cardiovascular risk factors in hemodialysis and peritoneal dialysis patients. Clin Biochem. 2007; 40: 1361-1366. 